\title{
Developing Radio Histories
}

In at least fifteen countries worldwide a century of radio is, or will be, celebrated in 2019 and following years. Looking in more detail at these celebrations, it is obvious that several technological breakthroughs connected to wireless transmission of sounds are considered to be the most important events structuring radio history. Pioneers or 'fathers' of radio are all technicians like Guglielmo Marconi (Italy), James Maxwell (UK), Reginald Fessenden (Canada), Lee de Forest, Edwin Armstrong, Charles Herrold, Frank Conrad (USA), Alexander Popov (Russia), Roberto Landell de Moura (Brasil), Heinrich Hertz (Germany), Edouard Branly and Eugene Ducretet (France), Nicola Tesla (Serbia), Robert von Lieben (Austria), Valdemar Poulsen (Denmark) and Hanso Idzerda (The Netherlands). This is remarkable because the technical history of radio is just one side of this specific part of media history. Looking at the development of radio historiography most of the stories are in fact about broadcasting, i.e. the social and cultural sides of the use of radio. Then a totally different type of event and many different individuals come to the fore: entrepreneurs, policy makers, politicians, musicians, writers and actors. Other scholars have pointed out that women were vital in the development of radio into a mass medium and that the white western perspective on radio history prevents us from considering vitally important social and cultural practices around radio broadcasting in other parts of the world. ${ }^{\mathrm{I}}$

It has been argued convincingly that seeing radio history solely as technologically driven limits our view on this field of research. According to the British radio historian Hugh G.J. Aitken (I922-I994) the focus on the technological exploits is a result of vanity: many historians prefer to talk about success rather than failure, and about visible and lasting results rather than frustrating setbacks. ${ }^{2}$ Therefore, a limited perspective on technical history is finalistic or deterministic in view; it focuses on successful breakthroughs and merely follows the historical developments back to their roots. It leads to neglecting or denying inventions that, while ultimately not successful, can still be called crucial for developing technology. It also blinds us from seeing the unpredictability of technology in interaction with societal or cultural changes. Indeed, there are many examples of the finest technological inventions having no success at all in changing society or culture. If it were that simple, investment in the best technology would be a sure way to obtain the highest profits. Obviously it is not, because history also shows numerous examples of profitable breakthroughs that were not predicted and even rejected, but in the long run became very successful because in social life they created unforeseen possibilities. Thus, in economic and media history leading scholars assert that technology is not the result of an autonomous technical process but is in fact 'socially constructed'.3 
The American radio historian Susan Douglas for instance characterises the history of radio not as a purely technological story, but as 'the social construction of broadcasting'. ${ }^{4}$ In the search for this social construction it is vital to understand that the medium we call 'radio-broadcasting' resulted from a series of more or less coincidental technical applications; each of these connected to different factors in the contemporary social environment, cultural practices and norms. The reconstruction of this technological, social and cultural network resulting in human behaviour and cultural communication can be characterised as 'media archaeology', a concept that has gradually developed in historical media studies during the last two decades. ${ }^{5}$

Looking at the scholarly development one can clearly discern a continuous but less prominent place for technological histories in combination with different phases in politically and culturally driven radio histories. The enormous societal and political meaning of broadcasting in what has become known as 'the golden age of radio' (between I920 and I960) also triggered scholarly interest. A logical first step in the interwar years was research into legal and political regulation and radio policies. This primarily took place within national contexts although broadcasting literally crossed boundaries. In the growing number of studies on the institutionalisation of broadcasting since the Second World War the focus was on the broader context of national, political and media institutions and cultural norms and identities. Issues like national and ideological identities, propagandistic influence, journalistic meaning and societal reaction dominated historiography. ${ }^{6}$

Following the experiences with the first visible mass reactions to radio, there was some interest in the social and cultural sides of radio programming. In the USA a pioneer study into the psychology of radio was published in I935, followed by famous research into the content of and reactions to the CBS-airplay War of the Worlds in September I938. The latter, which was the first empirical study into listening behaviour, also took into account other factors influencing daily human behaviour such as age, residence, gender, education, wealth, class and other social circumstances. ${ }^{7}$ In times that radio was seen mainly in relation to its effects on 'the masses' this differentiation was a real eye-opener.

As a result of the increasing role of television after the Second World War the interest in radio history faded. However, it was revived in the I970s and I980s as the focus of media studies shifted to the public in relation to media contents. Fundamental to this renewed interest was the creation of international journals partly or totally dedicated to radio studies, like the German Studienkreis Rundfunk und Geschichte (Research group of broadcasting and history, I974) and a leading role was played by the international scientific journal Historical Journal of Film, Radio and Television (1981). In the Netherlands, in 1989, the academic Jaarboek Mediageschiedenis (Annual media history) was founded, that later developed into the current TMG - Journal for Media History. Since the I990s several other specialised journals on radio emerged, including the Journal of Radio Studies (1992-2007), which is now the Journal of Radio and Audio Media (2008) and the Radio Journal: International Studies in Broadcast a Audio Media (2003).

In the growing academic interest in radio history in the early twenty-first century, the influence of cultural studies is clearly apparent. One crucial result is a changing research perspective from the supply side (institutions and programmes) and its ideological contexts aiming for 
passive audiences, to the social context of listening as a dynamic practice with active audiences. One of the first to pioneer this approach was the British media historian Paddy Scannell in his study of everyday experiences of modern life through audio-visual media. ${ }^{8}$ On the other side of the Atlantic, Michele Hilmes wrote an equally pioneering study of the way radio has contributed to the 'imagined community' of the United States of America in the early years of the medium. ${ }^{9}$

Inspired by these examples, scholars have developed various new perspectives on radio since 2000. One fruitful approach has been to consider radio as a transnational medium, transcending the tendency to consider the medium in its national contexts only. ${ }^{10}$ This idea has yielded compelling studies of the meaning of radio in various aspects of international relations, such as, for example, European integration and the British Empire. ${ }^{\text {II }}$ Other scholars have been expanding on the bottom-up approach of cultural studies and explore the overlaps and interactions between technology, social (listening) behaviour, cultural identities and mentalities. ${ }^{\mathrm{I2}}$ Finally, scholars have started exploring the position of radio vis-à-vis other media going beyond the idea of a one-dimensional relation of autonomously creating transmitters and a consuming audience, but part of all sound dimensions in the public sphere. In this modern 'soundscape', as it is called, social connections grew in which collective and interactive radio listening were crucial factors. ${ }^{\mathrm{I}}$

It is obvious that analogue radio technology is fading away fast in the ever- growing digital media landscape. However, media history also points out that specific media do not simply vanish because of innovation or changes in technology, culture and society. Instead, there is a constant remediation process in which traditional media forms are challenged by new media and redefine themselves in new production modes, business models and content forms. In this remediation process broadcasters focus more on those qualities which are probably unique selling points for radio, i.e. the power of audible, non-visual content to induce imagination and the possibilities for immediate connection to live music and news for all possible preferences. The digitisation in media has even stimulated the social functions of radio, creating and cultivating identities and tastes through music, opinion and sharing. The social function has gained weight by the interactive possibilities enabling audiences to shift their attention as fast as they like to relevant content that fits their imagination, experiences and social networks.

The shift to the auditive experience resulted in new disciplines researching new concepts like sound, soundscapes, noise and listening. Maybe because the traditional foundations of recognisable technological forms (telephony, sound amplification, radio, television, et cetera) were abandoned, it developed into a field that was, in the words of American radio historian Michele Hilmes, 'always rising, never arrived'. ${ }^{\mathrm{I}}$ That may be so, but you can also see that it triggered studies looking into the role of sound in the human psyche using 'old fashioned' concepts like 'the magic of radio'. A classically trained radio historian such as Sean Street, for example, claimed that sound stimulates the human imagination enabling listeners (of radio, music or podcasts) to take a personal trip in time and space. ${ }^{5}$ That is especially relevant in times of large-scale media integration and convergence into one digital media world on the one side and an ensemble of active audiences choosing for content everyplace, anytime and anywhere. 
In the year in which the Netherlands celebrates its radio centenary, this special issue reflects on radio history and radio historiography. Instead of looking for an answer to the question who was the first in the world to start radio, we focus on the shifting perspectives on radio history in the twentieth-first century and aim to capture the latest trends in the field. This special issue does not radically take sides in the debates about the nature and possible research concepts connected to radio/listening/sound. Acknowledging the interaction of technology, the social and the cultural in the development of radio and broadcasting in history, we seek to offer insights from radio researchers from around the world who draw attention to a variety of different aspects that together paint a picture of the broad canvas that is radio scholarship today. Thus, the articles in this special issue offer a rich showcase of fresh and original case studies from prominent radio historians. Roughly, the issue can be divided into two parts. The first three articles offer reflections on long-term developments of certain radio practices and broadcasting formats, often in interaction with other media. The last three articles present more focused case studies of the use of radio in specific historical circumstances.

In his article, Hans-Ulrich Wagner reflects on the ways writers were active on the airwaves. He throws light on longue durée developments in the ways radio and literature interacted as a 'media ensemble' and provides us with examples of broadcasting practices of writers active in the first century of radio. The article is structured around different categories of engagement, showing that some writers used the medium to experiment with new literary forms, while others made open ideological propaganda for a regime they supported. These categories, which are mainly based on British and German examples, invite the readers to reflect on the entanglements of radio and literature, which they can supplement with their own examples.

Paul Rixon explores the radio listings published by daily newspapers; a source that is not very often used in media historical research. While at first sight they mainly appear as a form of information, reporting to the reader what the newspaper has been told will be broadcast that day, the article argues that radio listings and the associated highlights can tell us a lot about the intermedial relationship between radio and print media. The article analyses the ever-changing representation provided by the listings between the launching of radio broadcasting in the UK in the I920s to the end of the I980s, at the dawn of the digital era. The different forms the radio listings have taken, teaches us about the cultural intermediary role of newspapers and those that work there, who actively shape their coverage for particular taste groups. Listings have also been important in how newspapers have represented the geographic dimension of radio, showing where the stations were broadcasting from but also where they were located on the airwaves. Such spatial representations have changed over time depending on the political, cultural and social context.

In his contribution, Peter Hoar reflects on the societal role of radio in New Zealand. He places radio in the context of the imperial history of the country that started with the 1840 Treaty of Waitangi, which established a relationship between Māori, the indigenous people, and the British Crown. The text underpins all aspects of modern New Zealand, the history of which has been one of colonisation with Māori being displaced, despoiled, and deprived of their land, language, and culture. In line with this history of imperial control, radio broadcasting in 
New Zealand started off in the I920s with a British-styled BBC model that predominated until the I980s. In that decade the wholesale adaptation of neoliberal ideologies saw New Zealand's media restructured along commercial lines and at the same time there was a resurgence and revitalisation of Māori culture and influence in New Zealand. This article outlines the roles of imperialism in the development of New Zealand radio before analysing the rise of Māori broadcasting as a counter imperial response along with the increasing importance played the Māori language (Te Reo) in New Zealand's postcolonial media culture.

Turning our attention to radio in Spain under the Franco regime, Sergio Blanco Fajardo uses radio scripts that were made for the regime's censorship body. He highlights the narrative message in this source material to show how the radio was entangled with the sociopolitical events of the country. This insight can help to take apart the hermetic division between social spheres and elucidate the tensions, changes, destabilisations and crisis periods that occurred throughout the dictatorship in multiple fields. The article draws our attention to the discourse of broadcasts for women, and argues that these radio formats acted as a catalyst for state policies and the construction of the nationalist project. On the other hand, they also reveal the contradictions in the new femininity models manifested in Franco's regime. This case study therefore shows how radio can be envisioned both as a witness and as an agent of the transformations during the Franco dictatorship which defined much of the history of twentieth-century Spain.

In their article, Pekka Salosaari and Lasse Vihonen analyse Finnish radio broadcasting during the Second World War. At the time the medium was recognised globally as an essential propaganda instrument for reaching out to audiences across boundaries and frontlines and at the same time for manipulating domestic public opinion. Radio broadcasting was particularly relevant for Finland, which was repeatedly invaded by the Soviet Union from the so-called Winter War of I940 onwards. Finnish broadcasters reached out to other countries to mobilise help, but were also very much aware of tensions within their country's public opinion arising from the difficult geopolitical situation. They developed a radio format to address and resolve citizens' everyday worries in the midst of the war and simultaneously to form a network of secret proxies who in turn could gather information about and help to manipulate public opinion: the programme Jahvetin kirjelaatikko (Jahvetti's Letterbox). This programme became the most popular radio broadcast in Finland during the years of the so-called Continuation War I94I-I944 (following another Soviet invasion). This article, which is based on Finish primary sources that have not been discussed in English-language scholarship, provides solid proof that radio played an important role in information warfare in which the citizens' support for Finland's fight for its existence as an independent nation was at stake.

In her article Alejandra Bronfman outlines a new perspective on the transnational 'Radio Wars' in the Caribbean that erupted in the context of the region's contentious, noisy, violent politics of the I950s and early I960s. In the rapidly changing political contexts of the time, Haiti's Francois Duvalier and Cuban Fidel Castro rose to power, while in the Dominican Republic Rafael Trujillo's regime weakened and ended with his assassination in I96r. Actors across the ideological spectrum used cross-border broadcasts in their efforts to both undermine and prop 
up particular regimes. This article explores those radio wars, understanding them not just as an enactment of the complex hemispheric politics of the day, but also as the expression of a particular kind of utopian imagining of radio's potential for political mobilisation. Expanding on and engaging a burgeoning literature on radio in Latin America, this articles analyses unique source material about Caribbean cross-border radio broadcasting that adds fresh perspectives to histories of the Cold War, decolonisation, and the soundscapes of dictatorship and empire. More precisely, it moves beyond a Soviet-US binary, that is often present in existing Cold War literature, and considers the role of broadcasting and propaganda in the making of an inter-Caribbean war of frequencies that highlights the role of radio as an instrument of decolonisation.

\section{Notes}

I. Caroline Mitchell, Women and Radio: Airing Differences (London/New York: Routledge, 2000); Alejandra Bronfman, Isles of Noise: Sonic Media in the Caribbean (Chapel Hill: University of North Carolina Press, 20I6); Matt Mollgaard, Radio and Society: New Thinking for an Old Medium (Newcastle upon Tyne: Cambridge Scholars, 20I2).

2. Hugh G.J. Aitken, Syntony and Spark. The Origins of Radio (New York: John Wiley, I976), 2II-2I2.

3. Wiebe E. Bijker, Thomas P. Hughes and Trevor Pinch, ed., The Social Construction of Technological Systems: New Directions in the Sociology and History of Technology (Cambridge: MIT Press, 20I2); Lisa Gitelman and Geoffrey B. Pingree, ed., New Media, 1740-1915 (Cambridge: MIT Press, 2004); Jim Macnamara, The 21st Century Media (R) evolution: Emergent Communication Practices (New York: Lang, 20I4).

4. Susan J. Douglas, Inventing American Broadcasting 1899-1922 (Baltimore: John Hopkins University Press I987), 292 and further.

5. Erkki Huhtamo and Jussi Parikka, ed., Media Archaeology: Approaches, Applications and Implications (Berkeley: University of California Press, 20II); Wolfgang Ernst, Digital Memory and the Archive (Minneapolis: University of Minnesota Press, 2013).

6. These perspectives are for example dominant in general media historical books written in the I96os: Asa Briggs, The History of Broadcasting in the United Kingdom, Volume I (Oxford: Oxford University Press, I96I); Winfried B. Lerg, Die Entstehung des Rundfunks in Deutschland (Frankfurt am Main: J.Knecht Verlag, I965); Eric Barnouw, A Tower in Babel. A History of Broadcasting in the United States. Volume 1: to 1933 (New York: Oxford University Press, I966) and Edward Chester, Radio, Television, and American Politics (New York: Sheed and Ward I969).

7. Hadley Cantril and Gordon W. Allport, The Psychology of Radio. (New York: Harper \& Brothers, I935); H. Cantril, The Invasion from Mars. A Study in the Psychology of Panic. (Princeton University Press, I940)

8. Paddy Scannell, Radio, Television and Modern Life (Cambridge: Blackwell, i996).

9. Michele Hilmes, Radio Voices. American Broadcasting, 1922-1952 (Minneapolis/London: Minneapolis University Press, I997). Later she published a history of American radio that reached into the 200os: Michele Hilmes, Only Connect. A Cultural History of Broadcasting in the United States (Belmont: Thompson Wadsworth, fourth editon 20I4).

Io. A. Badenoch and G. Föllmer, Transnationalizing Radio Research: New Approaches to an Old Medium (Bielefeld: Transcript 2018).

II. Suzanne Lommers, Europe - on Air. Interwar Projects for Radio Broadcasting (Amsterdam: Amsterdam University Press, 2012); Simon Potter, Broadcasting Empire. The BBC and the British World, 1922-1970 (Oxford: Oxford University Press, 20I2).

I2. Susan Douglas, Listening In. Radio and the American Imagination, (Minneapolis: University of Minnesota Press, 2004); Michele Hilmes en Joe Loviglio (eds.), Radio Reader. Essays in the Cultural History of Radio, (New York: Routledge, 2002); H. J. Koch en H. Glaser, Ganz Ohr. Eine Kulturgeschichte des Radios in Deutschland, (Keulen: Böhlau Verlag, 2005); W. Hagen, Das Radio. Zur Geschichte und Theorie des Hörfunks Deutschland/USA (München: Wilhelm Fink Verlag, 2005); Kate Lacey, Listening Publics. The Politics and Experiences of Listening in the Media Age (Cambridge: Polity Press 2013). 
I3. Emily Thompson, The Soundscape of Modernity. Architectural Acoustics and the Culture of Listening in America 1900-1930 (Cambridge MA: MIT Press, 2002); Jonathan Sterne, The Audible Past. Cultural Origins of Sound Reproductions (Durham: Duke University Press, 2003); Carolyn Birdsall, Between Noise and Silence. Sound, Technology and Urban Space during Nazi Germany (Amsterdam: UVA 2010).

I4. Michele Hilmes, 'Is There a Field Called Sound Culture Studies? And Does it Matter?,' American Quarterly 57, no. I, March, 2005, 249-259.

I5. Sean Street, The Sound inside the Silence. Travels in the Sonic Imagination (London: Palgrave Macmillan, 20I9).

\section{Biographies}

Vincent Kuitenbrouwer is senior lecturer of the History of International Relations at the University of Amsterdam. He specialises in nineteenth and twentieth-century imperial history and colonial media. He is co-investigator on the 'Connecting the Wireless World' project, and is also the author of numerous publications including "Radio as a Tool of Empire. Colonial Broadcasting from the Netherlands to the Dutch East Indies in the I920s and I930s," Itinerario. International Journal on the History of European Expansion and Global Interaction 40, no. I (20I6). He currently works on Dutch international radio broadcasting in the era of decolonisation.

Anya Luscombe is associate professor of media at University College Roosevelt, Utrecht University, where she teaches rhetoric and journalism. Her research focuses on radio history and Eleanor Roosevelt. She is the author of BBC Radio News, from the Swinging Sixties to the Turbulent Noughties (2013) and co-editor of Eleanor Roosevelt's Views on Diplomacy and Democracy (Palgrave: forthcoming). She is a former BBC journalist, has been a Fulbright scholar at Bard College, New York, and a research fellow at the Dutch Institute of Sound \& Vision.

Huub Wijfes is associate professor in Journalism Studies and Media History at University of Groningen and professor in History of Radio and Television at University of Amsterdam. He is the author of fifteen books and numerous articles on Media History, Media Policy, Political History and Journalism. His most recent books were on the history of Dutch Public Service Broadcasting: VARA, biografie van een omroep (2009) and on Journalism: Journalistiek in Nederland 1850-2000. Beroep, organisatie en cultuur (2004). In 2019 he published the first two of a three volume book series on the history of Dutch media platforms in international context: newspaper, radio and television. He was founder and editor of the scientific journal Tijdschrift voor Mediageschiedenis, now the academic open access journal TMG - Journal for Media History. 